\title{
Recycling and Mechanical Characterization of Polymer Blends Present in Printers
}

\author{
Ana Paula Adama, José Victor Rebechi Valle Gonçalves ${ }^{a}$, Luiz Carlos Robinson ${ }^{a}$, \\ Larissa Conde da Rosa ${ }^{a}$, Eduardo Luis Schneidera * \\ a Instituto de Ciências Exatas e Tecnologias, Feevale University, ERS-239, 2755, Vila Nova, CEP \\ 93525075, Novo Hamburgo, RS, Brazil
}

Received: December 17, 2016; Revised: May 15, 2017; Accepted: May 23 , 2017

\begin{abstract}
More and more electronic devices are being produced and most of them are disposed of improperly. In addition, as they contain heavy metals and toxic substances in their composition, the environmental impact increases. This work aims to study the recycling of polymers present in e-waste through the mechanical characterization of polymer blends produced with the main polymers present in printers. To do so, printers were dismounted, the material of the components was classified, and the main polymers were processed. The sample consisted of 20 printers, from which HIPS- $90 \% / \mathrm{PS}-10 \%$, HIPS-90\%/ ABS- $10 \%$ and HIPS- $100 \%$, blends were processed by extrusion and injection of specimens with tensile test geometry. The tensile strength was 39.0 MPa for HIPS/ABS, and 37.5 MPa for HIPS/PS. Despite having slightly different mechanical properties, probably due to possible variations in their chemical composition, the formulations have good quality and potential for use in new products such as hangers, organizing boxes, soles and, watering cans.
\end{abstract}

Keywords: Recycling, Polymer blends, Mechanical characterization, Electronic devices

\section{Introduction}

With the emergence of more modern electronic devices, access to quick communication has become essential and the purchase of these products has become indispensable. Consequently, the accumulation of electronic waste is increasing according to demand, since the average lifetime of a printer is about 5 years ${ }^{1}$. Electronic waste represents around $8 \%$ of the urban waste volume worldwide ${ }^{2}$. In Europe about 10 million tons WEEE are produced each year ${ }^{3}$ and it is estimated that by 2020 the amount generated will reach a total annual tonnage of 12.3 million $^{4}$. Since many times fixing devices is not economically feasible, old electronics are discarded in large quantities. Among emerging countries alone, Brazil is the leader in generating this type of waste, accounting for about 17.200 tons of printers per year, which are eventually deposited in inappropriate places, polluting the environment because of the toxic substances present in these residues ${ }^{5,6}$.

These devices are made of metal, electronic (printed circuit boards - PCI's, speakers, capacitors, transistors, cables) and polymeric parts. The polymers typically used are the following: high impact polystyrene (HIPS), acrylonitrilebutadiene styrene (ABS), polystyrene (PS), polycarbonate (PC), polyoxymethylene (POM) also known as polyacetal, polypropylene (PP), polyethylene (PE), polybutylene terephthalate (PBT), styrene acrylonitrile (SAN) and unidentified polymers. The polymers most commonly found

* e-mail: eduardoluis@feevale.br in e-waste are HIPS, with approximately $50 \%$ in weight, and ABS, which are commonly found in the shells ${ }^{7,8}$.

HIPS is a polymer that has between 4 and $9 \%$ of polybutadiene rubber (BR), also known as cis-butadiene, in their composition, allowing the material to have a greater impact resistance. Therefore, they are widely used in electronic appliances and can be processed at temperatures between 180 and $250{ }^{\circ} \mathrm{C}$. In addition, they admit tensile strength (yield stress) from about 20 to $41.4 \mathrm{MPa}$ and elongation between 22 and $65 \%$ \%, $10,11,12,13$.

ABS is a terpolymer with optimal properties due to the three types of polymer present in the composition, which confer rigidity and impact resistance. Their processing temperature is between 220 and $260{ }^{\circ} \mathrm{C}$, the tensile strength between 27,6 and $55 \mathrm{MPa}$ and elongation between 5 and $60 \%{ }^{10,12,13,14,15,16}$.

PS is a rigid homopolymer with a high chemical resistance, and a processing temperature between 160 and $280^{\circ} \mathrm{C}$. Their tensile strength is between 14 to $83 \mathrm{MPa}$ and elongation between 1.2 and $2.5 \%{ }^{10,13,14,15,17}$.

Polymeric chains of the thermoplastics flow with the application of temperature. This ability ensures a basic characteristic to these materials: they are recyclable, as it is possible to subject the materials to the same process again and again, and the flow effect persists. Due to this feature the products are widely used for the manufacturing of articles by molding processes, especially by extrusion and injection ${ }^{18}$. To obtain post-consumption recycled polymeric blends is essential to understand the behavior of mixtures in order to control the properties. Thus, binary and ternary 
blends have been widely studied using different additives and compatibility methods ${ }^{19}$.

Some of the main laws and regulations dealing with electrical and electronic waste are: the Basel Convention; The WEEE directives (Waste Electrical and Electronic Equipment) and RoHS (Restriction of the Use of Certain Hazardous Substances in Electrical and Electronic Equipment) in the European Union; The China RoHS and the Home Appliance Recycling Law in Japan ${ }^{20,21}$. The RoHs and WEEE directives are documents designed to regulate materials that are used in electronic equipment whose main objectives are to reduce the waste of these equipment at the end of life (EoL), to improve their waste recycling, as well as minimizing the impact on the environment ${ }^{22,23}$. These laws and regulations provides the restriction on the use of hazardous substances in electronic equipment, such as cadmium in pigments, mercury in relays, lead in solder, hexavalent chromium in corrosion protection layers and polybrominated biphenyls ether (PBDEs), which are widely used as a flame retardant in polymers. So potentially hazardous substances should be avoided in the development of recycled materials, especially for products that children can handle and put in their mouths, such as toys. In most Latin American countries recycling activity is dominates by the informal sector and the legal and regulatory framework for WEEE management usually does not include explicit provisions for the protection of health. In Brazil, there is the law 12,305 of 2010, referring to the National Solid Waste Policy (Política Nacional de Resíduos Sólidos - PNRS), which disciplined the integrated management of solid waste. The law defines that manufacturers, importers, distributors and marketers of electronics are required to structure and implement reverse logistics systems, by returning products after use by the consumer, independently of the public service of urban cleaning ${ }^{24,25,26}$. In relation to the use in food packaging, the permission or restriction of recycled materials intended for contact with food is defined in specific regulations, and for polymers, only the post-consumer polyethylene terephthalate (PET) is foreseen ${ }^{27}$.

The incorporation of styrene-butadiene-styrene thermoplastic rubber has been proposed to recover the mechanical properties of recycled high impact polystyrene ${ }^{28}$. Another study has examined the effects of adding commercial styrene-butadiene multiblock (SBS) and styrene-(ethylene-butylene)-styrene linear triblock (SEBS) copolymers to HDPE and HIPS postconsumer blends and has shown SEBS is more efficient as an interfacial tension modifier when than $\mathrm{SBS}^{29}$. Characterization and recycling of post-consumption monitor carcasses has also been studied and the results show that, regardless of the brand, manufacturers use ABS. However, there were variations in the mechanical assays possibly due to their different compositions ${ }^{30}$.

This paper studies the recycling of three major polymers present in electronic equipment, by collecting and dismantling printers of different brands and models, and were classified by the material of the components, and chemically characterized by Fourier Transform Infrared Spectroscopy (FTIR) technique. The printers manufacture year was not included in the classification because printers of same models may have been produced for many years. Blends of HIPS-90\%/PS-10\%, HIPS-90\%/ABS10\% and HIPS- $100 \%$ were processing by extrusion and molding by injection of specimens for mechanical characterization by tensile test.

\section{Materials and Methods}

First, we analyzed 20 printers donated from the company Otser Comércio de Resíduos e Sucatas (Otser Commerce of Waste and Scrap), located in the city of Campo Bom, in Rio Grande do Sul, the southernmost state of Brazil. This company collects unused electronic equipment from the population and sells parts and components. The printers were cataloged by brand and model specifications. Subsequently, the printers were weighed and disassembled. The disassembly process was timed and performed with manual disassembly.

The next step was to separate the material into metals (screws, axles and engine components), electronics (printed circuit boards - PCI's, speakers, capacitors, transistors, cables) and polymeric parts. The polymers were divided into HIPS, ABS, PS, PC, POM, PP, PE, PBT, SAN, and unidentified polymers. Subsequently, the proportions of the identified polymers (by visual inspection and FTIR) were weighed and analyzed. The polymers found in greater quantities, which were HIPS, ABS and PS, as per their identification codes, were comminuted separately in an industrial shredder (SEIBT, model T5 2x20/600). Particle size reduction was carried out in a knife mill (SEIBT, model MGHS 1.5/85), with a $6 \mathrm{~mm}$ sieve. The mass formulations were made from the comminuted materials consisting of $90 \%$ of HIPS with $10 \%$ of PS, $90 \%$ HIPS with $10 \%$ of ABS, and pure HIPS, followed by extrusion of the different compositions for greater homogenization of the materials in an extruder (SEIBT, model ES 25), with rotation speed of $5.2 \mathrm{rad}^{-1} \mathrm{~s}^{-1}$ and temperatures in the four zones at $160,170,180$ and $190^{\circ} \mathrm{C}$. The extruded material was then pelletized in a shredder (AX Plásticos, model AX GRA N). Figure 1 shows the five steps, from the separation process to the production of pellets of the suggested blends with polymers from the printers.

The pellets were used to inject specimens number IV of ASTM D 638-03 of each formulation, with $6 \mathrm{~mm}$ wide and $2 \mathrm{~mm}$ thick. An injector (BONMAQ, model APTA 80) was used, with temperatures set at $170,180,185$ and $190^{\circ} \mathrm{C}$ in the four zones, dosage of $115 \mathrm{~mm}$, speed of $60 \mathrm{~mm} \cdot \mathrm{min}^{-1}$ and pressure of 60 bar. Subsequently, tensile strength tests were carried out using a dynamometer (MAQTEST, model 354), with load cell of $200 \mathrm{Kgf}$ and test speed of $100 \mathrm{~mm}$.min-1. A 


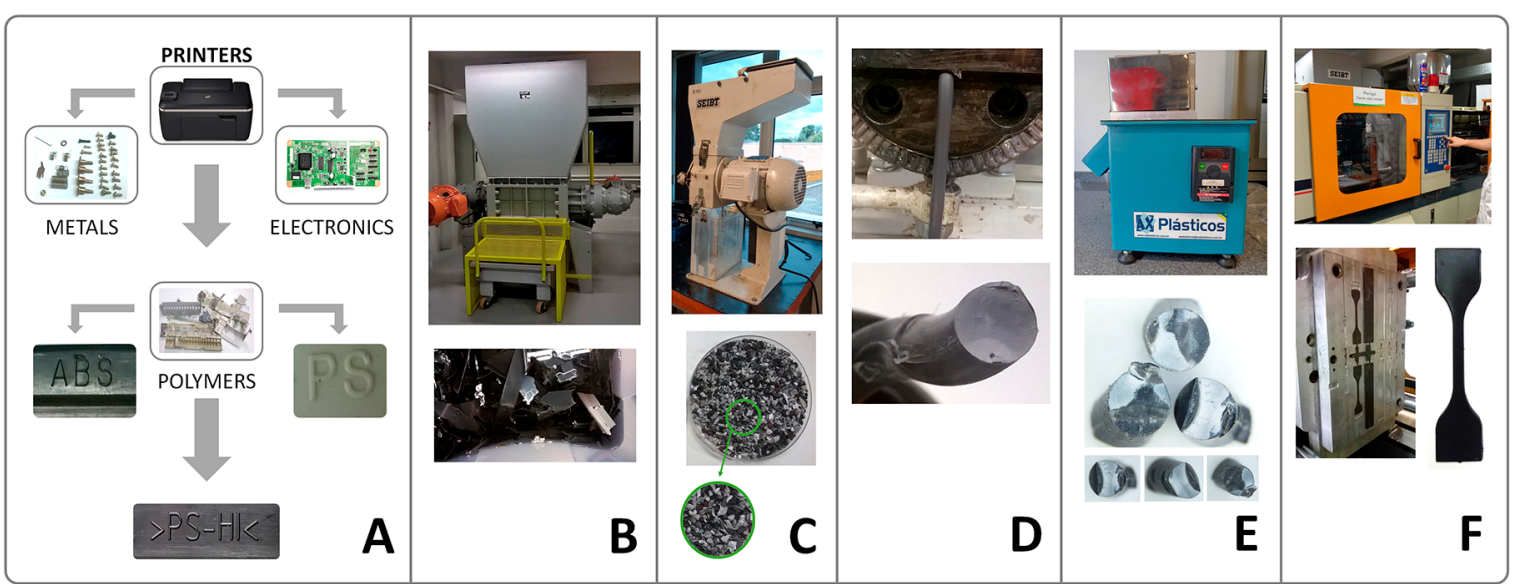

Figure 1. Separation process (A), comminution (B and C), extrusion (D), pelletization (E) and injection (F) of polymers from the printers.

total of 40 assays for each formulation was conducted, and the averages for yield strength and elongation were calculated.

The analyzes for chemical composition evaluation were made in the Fourier Transform Infrared Spectroscopy, FTIR, (Perkin Elmer, model Spectrum Two), with temperatures from 25 to $1000^{\circ} \mathrm{C}$, nitrogen flow of $100 \mathrm{~mL} \cdot \mathrm{min}^{-1}$ and heating rate of $20^{\circ} \mathrm{C} \cdot \mathrm{min}^{-1}$.

\section{Results and Discussion}

Results show that the times relating to the disassembly varied considerably, since each model has different weight, number of parts and size.

Hence, more robust printers with scanner (a total of 7 printers) took from 60 to $83 \mathrm{~min}$ to be disassembled, whereas smaller printers (a total of 13 printers) took between 39 and $59 \mathrm{~min}$. The total average time of disassembly of the 20 printers was $55 \mathrm{~min}$. We also found that, on average, about $54.0 \%$ of a printer's weight consists in polymers and this percentage is related to the size and year of manufacture, because older printers have more metals in their composition, such as EPSON LX300. Table 1 shows the disassembled printers with information on brand, model, photography, quantity, disassembly time and ratio of polymers.

Within the average polymeric fraction of $54.0 \%$, the most frequently found polymers in mass percentage were HIPS, with approximately $62.7 \%$, which is commonly found in the casing. ABS, with approximately $18.4 \%$, and PS, about $3.4 \%$, which are found in the internal parts responsible for paper rolling and protection of other parts, in addition to other polymers in smaller quantities, which together correspond to approximately $15.5 \%$, such as PC, POM, PP, PE, PBT, SAN and unidentified polymers. However, the lack of identification in certain parts hindered the separation process, reducing the number of polymers that could be properly routed to the next steps.
After the comminution process, the masses were measured to produce $2 \mathrm{~kg}$ of sample for each formulation. For example, $1.8 \mathrm{~kg}$ of HIPS with $0.2 \mathrm{~kg}$ of PS or ABS, representing $10 \%$ in weight. After the comminution, extrusion and pelletization, the processed material was weighed again. We found that there was loss of approximately $0.2 \mathrm{~kg}$ of material, that is, there was a loss of approximately $10 \%$ of the material during the processing of the polymeric components present in the printers into pellets.

Tensile tests showed that HIPS-90\%/ABS-10\% had the best performance, with an average yield strength of $39.0 \mathrm{MPa}$ and elongation of $46.2 \%$, followed by HIPS- $90 \% /$ PS- $10 \%$ with an average yield strength of $37.5 \mathrm{MPa}$ and elongation of $39.1 \%$. HIPS- $100 \%$ obtained an average yield strength of $45.1 \mathrm{MPa}$ and elongation of $14.9 \%$, as shown in Table 2 . Therefore, $10 \%$ of ABS increased elongation of HIPS by about $31.3 \%$ and decreased the yield strength by $6.1 \mathrm{MPa}$. On the other hand, $10 \%$ of PS increased elongation of HIPS by $24.2 \%$ and decreased the yield strength by $7.6 \mathrm{MPa}$.

According to the literature, elongation of PS ranges from 1.2 to $2.5 \%$ and yield strength is up to $51.7 \mathrm{MPa}$. Yield strength of HIPS may be up to 41.4 MPa. However, in the tensile strength tests resulted in different values for both. Elongation results were significantly better in the formulation with PS than in the formulation with HIPS, with an increase of $24.2 \%$ of the first in relation to the latter. On the other hand, in the formulation with HIPS the yield strength was 45.1 $\mathrm{MPa}$, showing a difference of $3.7 \mathrm{MPa}$, probably due to the amount of elastomer present in the HIPS of the printers ${ }^{13}$. As the price of HIPS is slightly higher, the findings of this study indicate that many components that were identified as HIPS could actually have a different chemical composition, one that is closer to PS. Another issue that must be taken into account is that the chemical composition of HIPS is typically $85-95 \%$ of styrene and $5-15 \%$ cis-butadiene rubber (BR) with graft copolymerization. Some types may use other rubbers: styrene-butadiene rubber (SBR), ethylene propylene diene 
Table 1. Information about the printers.

\begin{tabular}{|c|c|c|c|c|c|}
\hline Trademark & Model & Image & Amount & Dismantling (min) & Polymer weight amount (\%) \\
\hline CANON & BJC 240 & & 1 & 48 & 58.7 \\
\hline \multirow{5}{*}{ EPSON } & CX5600 & & 3 & $39-43-56$ & $57.3-58.0-62.2$ \\
\hline & FX880+ & & 1 & 75 & 76.0 \\
\hline & LX300 & & 4 & $43-57-62-75$ & $24.4-27.1-27.4-48.8$ \\
\hline & $\mathrm{T} 33$ & & 1 & 44 & 57.0 \\
\hline & TX 125 & & 1 & 83 & 72.1 \\
\hline \multirow{8}{*}{ HP } & 3050 & & 1 & 48 & 51.1 \\
\hline & 3516 & & 1 & 65 & 59.2 \\
\hline & $660 \mathrm{C}$ & & 1 & 58 & 44.5 \\
\hline & D1560 & & 1 & 45 & 57.1 \\
\hline & D1660 & & 1 & 40 & 57.3 \\
\hline & D2360 & & 2 & $45-45$ & $60.1-62.1$ \\
\hline & F380 & & 1 & 67 & 59.5 \\
\hline & PSC1210 & + & 1 & 62 & 59.9 \\
\hline & & & Total: 20 & Average: 55 & Average: 54.0 \\
\hline
\end{tabular}

Table 2. Yield strength and elongation values of tensile strength tests.

\begin{tabular}{lcc}
\hline Formulation & $\begin{array}{c}\text { Average of Yield } \\
\text { Strength (MPa) }\end{array}$ & $\begin{array}{c}\text { Average of } \\
\text { Elongation (\%) }\end{array}$ \\
\hline HIPS-90\% / ABS-10\% & 39.0 & 46.2 \\
HIPS-90\% / PS-10\% & 37.5 & 39.1 \\
HIPS-100\% & 45.1 & 14.9 \\
\hline
\end{tabular}

(EPDM), or styrene-butadiene-styrene (SBS) ${ }^{15}$. Furthermore, the possible presence of flame retardant additives, usually organic brominated or, more recently, halogen-free, also vary the compositions of HIPS and may contribute to the variation in results and the consequent difference found in average values of yield strength and elongation.
With the pure materials analyzes done in the FTIR it was possible to notice that the bands between HIPS- $100 \%$ and PS-100\% are very similar (Figure 2) thus showing that the chemical composition of both materials are very similar. This explains the fact that the PS has contributed to the increase in HIPS elongation even though the values of the literature for this material are very low, between 1.5 and $2.5 \%$. It is also well known that in the range below $600 \mathrm{~cm}^{-1}$, where the halogenated alkanes are located, the bands are with high intensity in all spectra, demonstrating the possible addition of flame retardants in the composition of these polymers. Although no identifications were found regarding the addition of these additives in the chemical 

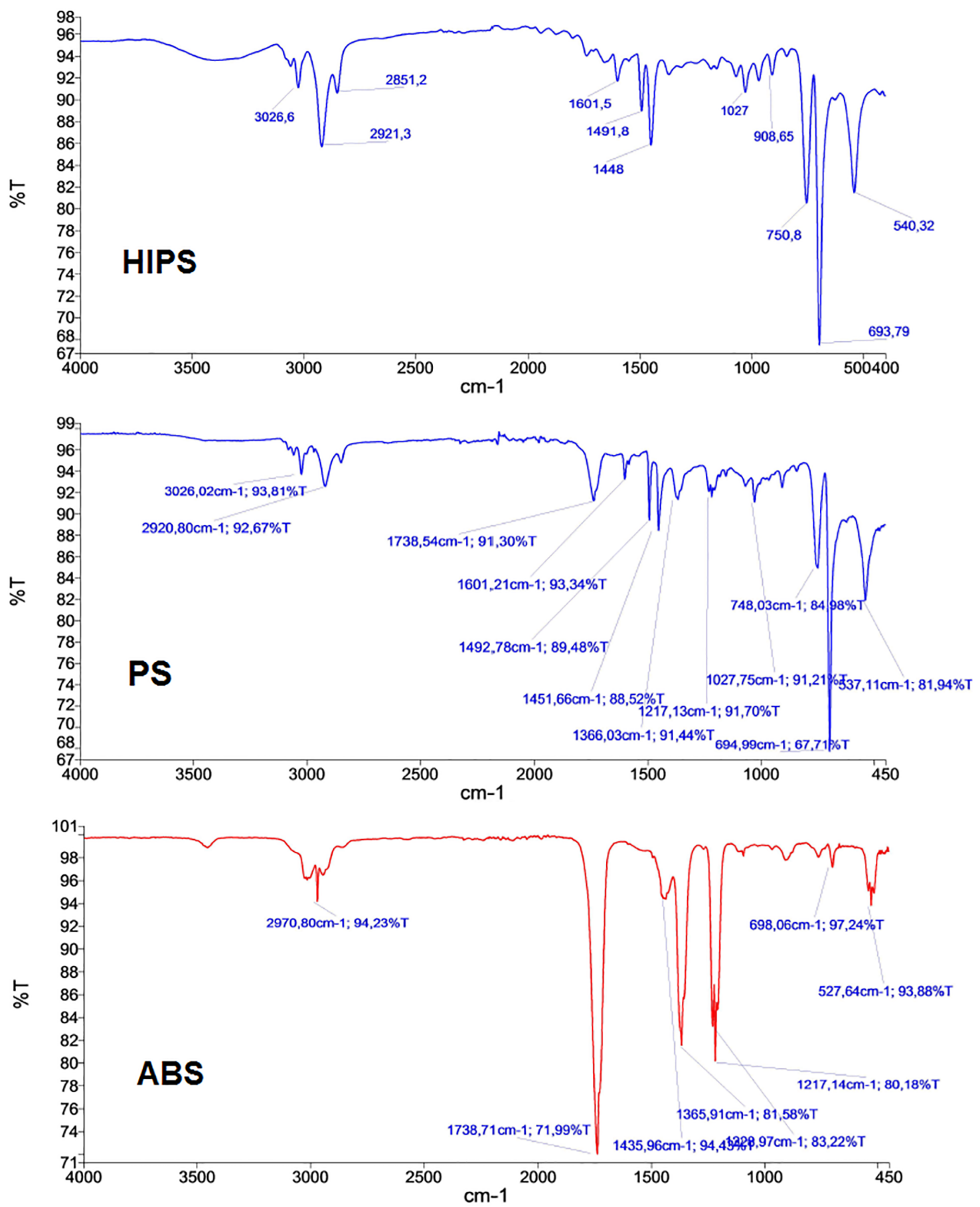

Figure 2. Spectrums graphs of HIPS- $100 \%$, ABS- $100 \%$ and PS- $100 \%$.

composition of the parts of the printers, another factor that influences the values obtained in the tensile tests.

Thus, considering the analyzed materials, the PS-100\% has similar characteristics to HIPS-100\%, justifying the difference between the values of yield strength (elastic limit) and elongation obtained in the tensile test and those according to the literature and the software Cambridge Engineering Selector (CES) 2015, Figure 3.

Comparing the default values of the CES and the values obtained in the tensile test, the results indicate that the polymer PS identified in the printers is not the default PS because there is a probable modification in the composition, such 


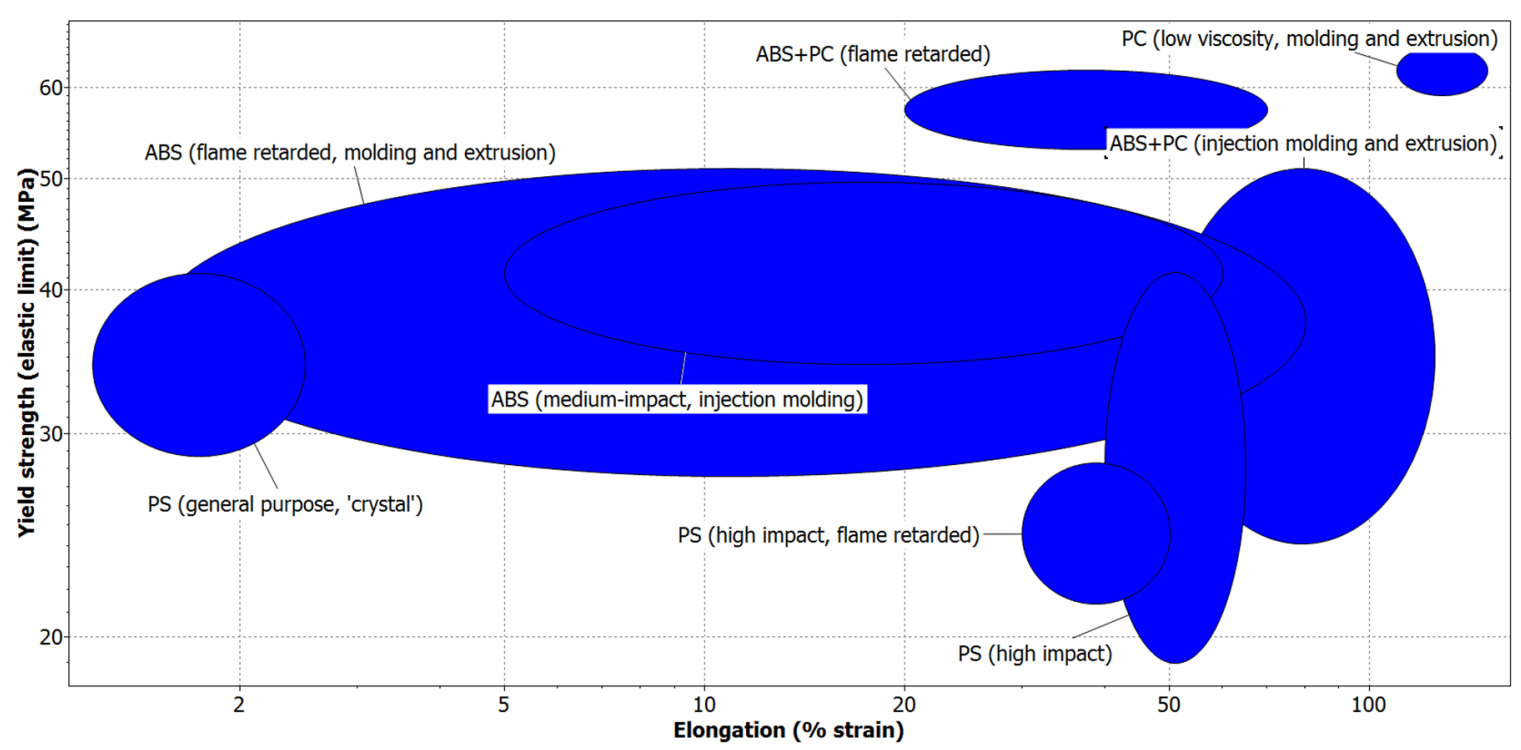

Figure 3. Values chart of the Yield Strength and the Elongation of CES (Cambridge Engineering Selector).

as the addition of cis-butadiene, one of the main elastomers found in HIPS.

\section{Conclusions}

Based on the challenge of reducing the significant amount of electronic waste discarded with the total urban waste volume worldwide, this work was proposed as a way to technically enable the reuse of a higher proportion of the polymers present in printers by studying the mechanical behavior of different blends.

The results showed that the disassembly time of the printers depends on their size and number of parts, since the values varied between 39 and 83 minutes. As to the separation process, we found difficulties in the polymeric classification of the materials, since parts of the components contained no identification, impairing their subsequent recycling. In most printers, the polymeric mass is predominant. For the 20 printers disassembled this fraction amounted to an average of $54.0 \%$, while the remainder varies between electronic components and metallic materials. The majority of polymers we found in descending order are HIPS, ABS, PS, PC, POM, PP, PE, PBT and SAN. HIPS was three times more employed than ABS and together they correspond to more than four times the sum of the other polymers present in smaller quantities.

The HIPS formulation with $10 \%$ of ABS had the best performance of all, increasing elongation of HIPS by about $31.3 \%$, while the formulation with $10 \%$ of PS obtained a lower performance, increasing elongation by $24.2 \%$. The yield strength of both formulations decreased compared to the pure material, about $6.1 \mathrm{MPa}$ for $10 \%$ of $\mathrm{ABS}$, and 7.6 $\mathrm{MPa}$ for $10 \%$ of PS. Considering that the yield strength values of the tensile strength tests for HIPS (45.1 MPa) were different than the values reported in the literature (41.0 MPa), it seems that the amount and variety of elastomers present in HIPS is different in each printer. Furthermore, the possible addition of flame retardants in some cases may influence the values obtained in the tensile strength tests. In any case, despite having different behaviors, all formulations could potentially replace virgin polymers and be used in new products whose design requirements can be satisfied with their mechanical properties.

Despite the small difference in the mechanical properties among the HIPS-90\%/ABS-10\% and HIPS-90\%/PS-10\%, all formulations have good quality and high potential for use in new products that meet the properties of each material. Possible applications include household appliances in general, shovels for waste, hangers and computer equipment, sound and video shells.

\section{References}

1. Schluep M, Hagelueken C, Kuehr R, Magalini F, Maurer C, Meskers C, et al. Recycling - From E-Waste to Resources. Sustainable Innovation and Technology Transfer Industrial Sector Studies. Paris: United Nations Environment Programme; 2009. p. 41-44.

2. Gerbase AE, Oliveira CR. Reciclagem do lixo de informática: uma oportunidade para a química. São Paulo: Química Nova. 2012;35(7):1486-1492.

3. ITRE Committee. Directorate general for internal policies. Policy Department Economic and Scientific Policy, Industry, Research and Energy. How can European industry contribute to grow and foster European competitiveness? Brussels: European Parliament; 2014. Available from: <http://www. europarl.europa.eu/RegData/etudes/STUD/2014/536280/ IPOL_STU(2014)536280_EN.pdf $>$. Access in: 18/12/2015.

4. Muhammad C, Onwudili JA, Williams PT. Catalytic pyrolysis of waste plastic from electrical and electronic equipment. Journal of Analytical and Applied Pyrolysis. 2015;113:332-339. 
5. Kasper AC, Bernardes AM, Veit HM. Characterization and recovery of polymers from mobile phone scrap. Waste Management \& Research. 2011;29(7):714-726.

6. Kemerich PDC, Mendes SA, Vorpagel TH, Piovesan M. Impactos ambientais decorrentes da disposição inadequada de lixo eletrônico no solo. Engenharia Ambiental. 2013;10(2):208219.

7. Tange L, Drohmann D. Waste electrical and electronic equipment plastics with brominated flame retardants - from legislation to separate treatment - thermal processes. Polymer Degradation and Stability. 2005;88:35-40.

8. Jung SH, Kim SJ, Kim JS. Thermal degradation of acrylonitrilebutadiene-styrene (ABS) containing flame retardants using a fluidized bed reactor: The effects of Ca-based additives on halogen removal. Fuel Processing Technology. 2002;96:265270.

9. Hirayama D, Saron C. Characterisation of recycled acrylonitrilebutadiene-styrene and high-impact polystyrene from waste computer equipment in Brazil. Waste Management \& Research. 2015;33(6):543-549.

10. Hirayama D. Reciclagem do copolímero acrilonitrila-butadienoestireno e do poliestireno de alto impacto oriundos de rejeitos de equipamentos elétricos e eletrônicos na forma de blendas poliméricas. [Thesis]. São Paulo: Universidade de São Paulo; 2015 .

11. Borrerly DF. Estudo comparativo da degradação de poliestireno e de poliestireno de alto impacto por envelhecimento natural $e$ artificial. [Dissertation]. São Paulo: Universidade de São Paulo; 2002.

12. Peydro MA, Juarez D, Sanchez-Caballero S, Parres F. Study of the Mechanical Properties of Acrylonitrile Butadiene Styrene High Impact Polystyrene Blends with Styrene Ethylene Butylene Styrene. Annals of the Oradea University. 2013;22(1):269-272.

13. Jones DHR, Ashby M. Engineering Materials v. 1 - Properties and Applications, $3^{\text {rd }}$ ed An Introduction to Properties Applications and Design. Oxford: Butterworth-Heinemann; 2005.

14. Kalpakjian S, Schmid SR. Properties and Processing of Polymers and Reinforced Plastics: Rapid Prototyping and Rapid Tooling. In: Kalpakjian S, Schmid SR. Manufacturing Processes for Engineering Materials. London: Pearson; 2008. p. 584-667.

15. La Mantia F. Handbook of Plastics Recycling. Shawbury: iSmithers Rapra Publishing; 2002.

16. Ozcelik B, Ozbay A, Demirbas E. Influence of injection parameters and mold materials on mechanical properties of ABS in plastic injection molding. International Communications in Heat and Mass Transfer. 2010;37(9):1359-1365.

17. Callister Júnior WD. Ciência e Engenharia de Materiais: Uma Introdução. Rio de Janeiro: LTC; 2012.
18. Mano EB, Mendes LC. Introdução a Polímeros. São Paulo: Edgard Blucher; 1999.

19. Manrich S, Santos ASF. An Overview of Recent Advances and Trends in Plastic Recycling. In: Loeffe CV. Conservation and Recycling of Resources: New Research. Hauppauge: Nova Science Publishers; 2006. p. 1-60.

20. European Comission. The Directive 2002/96/EC of the European Parliament and of the Council of 27 January 2003 on waste electrical and electronic equipment (WEEE). Journal of the European Communities. 2003;37:24-38.

21. Vanegas P, Peeters JR, Dewulf W, Cattrysse D, Duflou JR. Improving Resource Efficiency through Recycling Modelling: A Case Study for LCD TVs. Procedia CIRP. 2015;26:601-606.

22. Ryan A, Donoghue LO, Lewis H. Characterising components of liquid crystal displays to facilitate disassembly. Journal of Cleaner Production. 2011;19(9-10):1066-1071.

23. Goodman P, Robertson C. Review of Directive 2002/95/EC (RoHS) Categories 8 and 9. Leatherhead: ERA Technology.

24. São Paulo. Lei $N^{o} 13.576$, de 6 julho de 2009. Institui normas e procedimentos para a reciclagem, gerenciamento e destinação final de lixo tecnológico. São Paulo: Diário Oficial do Estado de São Paulo; 2009.

25. Torres V, Borger FG. Política Nacional de Resíduos Sólidos e seus Desafios para a Indústria de Eletroeletrônicos: Estudo de Caso Hewlett Packard Brasil. In: Kruglianskas I, Pinsky VC Gestão Estratégica da Sustentabilidade - Experiências Brasileiras. Rio de Janeiro: Elsevier; 2014. p. 149-171.

26. Brasil. Lei $\mathrm{N}^{\mathrm{o}} 12.305$, de 2 de agosto de 2010. Institui a Política Nacional de Resíduos Sólidos; altera a Lei no 9.605, de 12 de fevereiro de 1998; e dá outras providências. Diário Oficial da União, Brasília, DF, 03 ago. 2010a. Available from: <http:// www.planalto.gov.br/ccivil_03/_ato2007-2010/2010/lei/112305. htm>. Access in: 28/05/2017

27. Brasil. Ministério da Saúde. Agência Nacional de Vigilância Sanitária. Resolução de diretoria colegiada $-R D C n^{\circ} 20$, de 26 de março de 2008. Altera a Resolução RDC n'. 02 , de 25 de janeiro de 2010, que dispõe sobre o gerenciamento de tecnologias em saúde em estabelecimentos de saúde. Brasília: Ministério da Saúde; 2012.

28. Ribeiro VF, Domingues NSJ, Riegel IC. Estudo da recuperação das propriedades mecânicas de poliestireno alto impacto (HIPS) reciclado através da incorporação de borracha termoplástica tipo estireno-butadieno-estireno (SBS). Polímeros. 2012;22(2):186-192.

29. Perez ISB, Manrich S, Manrich S. Efeito da adição de diferentes copolímeros em blendas HDPE/HIPS pós-consumo: morfologia de fases e propriedades térmicas. Polímeros. 2008;18(3):207-214.

30. Gabriel AP, Grochau IH, Santana RMC, Veit HM. Reciclagem de carcaças de monitores: propriedades mecânicas e morfológicas. Polímeros. 2013;23(6):823-831. 